\title{
Pathophysiologic Findings of Irritable Bowel Syndrome in China
}

\author{
Likun Zhong and Xiaohua Hou* \\ Division of Gastroenterology, Union Hospital of Tongji Medical College, Huazhong University of Science \& Technology, Wuhan, China
}

The mechanism of irritable bowel syndrome (IBS) is still incompletely understood in the world although large amount of investigations have been carried out on it. There are many studies on the pathophysiology of IBS in China, which has huge amount of population suffering from IBS with special ethnicity and culture, including Mainland China, Hong Kong and Taiwan. We collected the literatures to show the results and discuss whether there were any differences in the pathophysiologic findings between China and other countries, whether there were any differences among different subtypes and how the pathophysiology correlated with the manifestations of patients. Gene polymorphism, disturbances of gastrointestinal motility, visceral hypersensitivity, intestinal infection and inflammation, psychological disturbances, food hypersensitivity and intolerance, and altered gut microflora were reviewed in this paper. Some conflicting outcomes between China and other countries were noted although most of them were similar.

(J Neurogastroenterol Motil 2012;18:19-33)

Key Words

China; Irritable bowel syndrome; Pathophysiology

\section{Introduction}

Irritable bowel syndrome (IBS) is a common functional gastrointestinal disorder (FGID) mainly manifested as abdominal pain and correlated changed bowel habits. The chief bowel pattern determines the classification of IBS subtypes, which was set through Rome III criteria in the recent years, including constipation predominant IBS (IBS-C), diarrhea predominant IBS (IBS-D), mixed IBS (IBS-M) and unsubtyped IBS (IBS-U). Since IBS can cause substantial decline in the quality of life for the patients and accounts for a great amount of hospital visits and economic burden for society, many investigations have been done on the mechanisms of pathophysiology for IBS. The commonly stated mechanisms include genetic factors, abnormal gastrointestinal (GI) motility, visceral hypersensitivity, psychological disturbances, intestinal inflammation and so on. However, the results of these investigations have often been conflicting and no specific pathophysiology has been demonstrated to be certain for IBS.

The prevalence of IBS is reported to be $2.9 \%-15.6 \%$ in Asian countries nowadays, ${ }^{1}$ which is nearly comparable to that in the Western countries. China is a great country with large amount of population, specific ethnicity and custom in Asia. IBS has been found to be common for Chinese in these years and many studies about IBS have been carried out recently. The results of these in-

Received: September 26, 2011 Revised: December 14, 2011 Accepted: December 22, 2011

(c) This is an Open Access article distributed under the terms of the Creative Commons Attribution Non-Commercial License (http://creativecommons. org/licenses/by-nc/3.0) which permits unrestricted non-commercial use, distribution, and reproduction in any medium, provided the original work is properly cited.

*Correspondence: Xiaohua Hou, MD, PhD

Division of Gastroenterology, Union Hospital of Tongji Medical College, Huazhong University Science and Technology, Jiefang Road 1277\#, Wuhan 430022, China

Financial support: None.

Tel: +86-27-8572-6930, Fax: +86-27-8572-6930, E-mail: houxh@public.wh.hb.cn

Conflicts of interest: None. 
vestigations on pathophysiology and differences in the results between China and other countries have not been comprehensively reported since most of the works in China were published in Chinese journals. To show the results from China and find out the answer, we collected the manuscripts on pathophysiology of IBS by searching for papers in Chinese databases and PubMed to comprise the studies from Mainland China, Hong Kong and Taiwan from 1989 to 2011. In this review, the investigations about pathophysiology in China would be shown from the aspects of genetic factors, disturbances of GI motility, visceral hypersensitivity, intestinal infection and inflammation, psychological disturbances, food hypersensitivity and intolerance, and altered gut microflora, which have been frequently reported. Furthermore, we intended to find out if there were any differences for mechanisms among different subtypes and how the pathophysiology correlated to the manifestations of IBS in China.

\section{Gene Polymorphism}

Lots of familial aggregation studies and twin studies have suggested that genetic factors perhaps influenced the susceptibility of IBS although the reports were somewhat conflicting. Up to now, the genes associated with serotonin, inflammation, adrenergic, mucosal barrier, and psychology which may play a role in IBS have been widely examined. ${ }^{2}$ In China, the investigations about gene polymorphism are extremely limited and most of them are involved in serotonin and inflammation. We tried to find out if there were any differences in the results of gene polymorphism between China and other countries. The main findings of the investigations from China and other countries were shown in Table 1.

Serotonin transporter (SERT) is a protein which reuptakes 5-hydroxytryptamine (5-HT) in synaptic cleft and then reduces the function of 5-HT such as inducing urgency, cramps, diarrhea and vomiting. ${ }^{3,4}$ The lower expression of SERT will indicate higher level of 5-HT, which may be associated with bowel symptoms in IBS patients. The 2 well investigated polymorphism regions are variable number tandem repeat (VNTR) and serotonin transporter linked polymorphic region (5-HTTLPR).

For the 5-HTTLPR region, there were different associations reported between the genotypes and various subtypes of IBS in different studies. But none of the investigations has found correlations between the genotypes and IBS overall which had not been categorized except for the study by Park. ${ }^{5-15}$ A metaanalysis comprising studies involving Caucasians or Asians also concluded that there was no association between 5-HTTLPR and IBS overall. ${ }^{16}$ The transcriptional activity of long $(\mathrm{L})$ allele is apparently greater than short (S) allele in 5-HTTLPR for SERT, then L/L genotype has higher transcriptional efficacy than $\mathrm{L} / \mathrm{S}$ and $\mathrm{S} / \mathrm{S}$ genotypes. All of the studies about 5-HTTLPR in China showed that IBS-C patients had significantly higher frequency of $\mathrm{L}$ allele or $\mathrm{L} / \mathrm{L}$ genotype than healthy individuals and patients of other subtypes. ${ }^{6-10}$ Besides, Zhang and $\mathrm{Lin}^{10}$ also exhibited that IBS-D patients had higher frequency of $\mathrm{S}$ allele and $\mathrm{S} / \mathrm{S}$ genotype than healthy controls and patients of other subtypes. The outcomes of investigations from other countries exhibited some discordance. Lee et $\mathrm{al}^{11}$ found no correlation between the polymorphism of 5-HTTLPR and overall or each subtype of IBS in Korea. While another study by Park et $\mathrm{al}^{5}$ which was also from Korea showed that $\mathrm{S} / \mathrm{S}$ genotype was more common in patients with IBS than healthy controls, especially in IBS-D subtype. The result of investigation by Kim et $\mathrm{al}^{12}$ from US was the same with Lee et al. ${ }^{11}$ Yeo et $\mathrm{al}^{4}$ found the frequency of $\mathrm{S} / \mathrm{S}$ genotype to be higher in female IBS-D patients than healthy controls in US. However, the investigations from Turkey by Pata et $\mathrm{al}^{13}$ and from India by Sikander et $\mathrm{al}^{14}$ both found the contradictory result that $\mathrm{S} / \mathrm{S}$ genotype was more common in IBS-C than controls. Niesler et $\mathrm{al}^{15}$ also showed that male IBS-D patients had lower frequency of $\mathrm{S} / \mathrm{S}$ genotype than controls in UK. Therefore, from the various results above, we could not obtain a firm conclusion about the relationship between polymorphism of 5-HTTLPR and IBS subtypes. But the results of investigations from China were almost the same for $\mathrm{L} / \mathrm{L}$ genotype associated with IBS-C, ${ }^{6-10}$ which was contradictory to the investigations by Pata and Sikander et al. ${ }^{13,14}$ In addition, the explanations for the conflicting phenomenon by them were also different. Wang et $\mathrm{al}^{6}$ speculated that the $\mathrm{L} / \mathrm{L}$ genotype for high expression of SERT caused 5-HT reuptake before the effects of 5-HT were shown and then attenuated the motility and secretion of intestine to cause IBS-C. However, Pata et $\mathrm{al}^{13}$ considered the $\mathrm{S} / \mathrm{S}$ genotype responding to the low expression of SERT which might have caused the aggregation of 5-HT and then downregulated the 5-HT receptors, therefore led to IBS-C.

Racial difference might be one of the reasons for the variations of these results since the distribution of 5-HTTLPR gene polymorphism varied among different races and regions. Homozygous for the $\mathrm{S}$ allele in Asians (64\% of patients) was reported to be markedly higher than that in Caucasians (22\% of patients) in a meta-analysis. ${ }^{16}$ Xie $\mathrm{J}$ et al ${ }^{17}$ investigated the polymorphism regions of 5-HTTLPR for healthy individuals of Han Chinese and found the frequencies of $\mathrm{S}$ allele and $\mathrm{S} / \mathrm{S}$ genotype to be pre- 
Table 1. Comparisons on Genetic Polymorphism for Irritable Bowel Syndrome in China and Other Countries

\begin{tabular}{|c|c|c|c|c|c|}
\hline Pathway & Locus & First author & Region & Overall IBS vs control & IBS subtype vs control \\
\hline \multirow[t]{17}{*}{ SERT } & \multirow[t]{11}{*}{ 5-HTTLPR } & Wang et $\mathrm{al}^{6}$ & Tianjin, China & No relation & $\begin{array}{l}\text { L/L in IBS-C higher than control and } \\
\text { IBS-D, IBS-A; L/S in IBS-D, IBS-A } \\
\text { higher than IBS-C }\end{array}$ \\
\hline & & Li et al ${ }^{8}$ & Guangdong, China & No relation & $\begin{array}{l}\mathrm{L} / \mathrm{L} \text { in IBS-C higher than control and } \\
\text { IBS-D, IBS-A }\end{array}$ \\
\hline & & Xie et $\mathrm{al}^{9}$ & Jiangxi, China & No relation & $\mathrm{L} / \mathrm{L}$ in IBS-C higher than control \\
\hline & & Zhang and $\operatorname{Lin}^{10}$ & Fujian, China & No relation & $\begin{array}{l}\mathrm{L} / \mathrm{L} \text { in IBS-C higher than control and } \\
\text { IBS-D, IBS-A; S/S in IBS-D higher } \\
\text { than control }\end{array}$ \\
\hline & & Lee et $\mathrm{al}^{11}$ & Korea & No relation & No relation \\
\hline & & Park et $\mathrm{al}^{5}$ & Korea & $\mathrm{S} / \mathrm{S}$ higher in IBS & $\mathrm{S} / \mathrm{S}$ in IBS-D higher than control \\
\hline & & Pata et $\mathrm{al}^{13}$ & Turkey & No relation & $\begin{array}{l}\text { L/S in IBS-D higher than control and } \\
\text { IBS-C, IBS-A; S/S in IBS-C higher } \\
\text { than IBS-D, IBS-A }\end{array}$ \\
\hline & & Sikander et $\mathrm{al}^{14}$ & India & No relation & $\begin{array}{l}\mathrm{S} / \mathrm{S} \text { more common in IBS-C than } \\
\text { non-S/S genotype }\end{array}$ \\
\hline & & Kim et $\mathrm{al}^{12}$ & US & No relation & No relation \\
\hline & & Yeo et $\mathrm{al}^{4}$ & US & - & $\mathrm{S} / \mathrm{S}$ in female IBS-D higher than control \\
\hline & & Niesler et al ${ }^{15}$ & UK & No relation & $\mathrm{S} / \mathrm{S}$ in male IBS-D lower than control \\
\hline & \multirow[t]{6}{*}{ VNTR } & Wang et $\mathrm{al}^{6}$ & Tianjin, China & $\begin{array}{l}\text { STin2.12/10 } \\
\text { higher in IBS }\end{array}$ & $\begin{array}{l}\text { STin2.12/12-L/L in IBS-C higher than } \\
\text { IBS-D, IBS-A }\end{array}$ \\
\hline & & Li et $\mathrm{al}^{8}$ & Guangdong, China & No relation & No relation \\
\hline & & Xie et $\mathrm{al}^{9}$ & Jiangxi, China & No relation & No relation \\
\hline & & Zhang and $\operatorname{Lin}^{10}$ & Fujian, China & No relation & No relation \\
\hline & & Pata et $\mathrm{al}^{13}$ & Turkey & No relation & No relation \\
\hline & & Niesler et $\mathrm{al}^{15}$ & UK & No relation & No relation \\
\hline \multirow[t]{10}{*}{ IL-10 } & \multirow[t]{4}{*}{$1082 \mathrm{G} / \mathrm{A}$} & Wang et $\mathrm{al}^{19}$ & Tianjin, China & - & No relation between IBS-D and control \\
\hline & & Santhosh et $\mathrm{al}^{21}$ & India & No relation & - \\
\hline & & Gonsalkorale et $\mathrm{al}^{22}$ & UK & $\mathrm{G} / \mathrm{G}$ lower in IBS & No relation \\
\hline & & Van der Veek et al ${ }^{23}$ & Dutch & No relation & No relation \\
\hline & \multirow[t]{3}{*}{$819 \mathrm{C} / \mathrm{T}$} & Wang et $\mathrm{al}^{19}$ & Tianjin, China & - & $\begin{array}{l}\mathrm{T} / \mathrm{T} \text { and } \mathrm{T} \text { allele in IBS-D higher than } \\
\text { control }\end{array}$ \\
\hline & & Santhosh et $\mathrm{al}^{21}$ & India & No relation & - \\
\hline & & Van der Veek et $\mathrm{al}^{23}$ & Dutch & No relation & No relation \\
\hline & \multirow[t]{3}{*}{$592 \mathrm{C} / \mathrm{A}$} & Wang et $\mathrm{al}^{19}$ & Tianjin, China & - & $\begin{array}{l}\mathrm{A} / \mathrm{A} \text { and } \mathrm{A} \text { allele in IBS-D higher than } \\
\text { control }\end{array}$ \\
\hline & & Jiang et $\mathrm{al}^{20}$ & Guangdong, China & $\begin{array}{l}\text { Allele } A \text { and } A / A \\
\text { higher in IBS }\end{array}$ & - \\
\hline & & Santhosh et al ${ }^{21}$ & India & Allele A higher in IBS & - \\
\hline \multirow[t]{2}{*}{ CNR1 } & \multirow[t]{2}{*}{$\begin{array}{l}\text { AAT triplet } \\
\text { repeats }\end{array}$} & Zhang et $\mathrm{al}^{26}$ & Guangdong, China & $\begin{array}{l}\text { Allele } \geq 10 \text { and } \geq 10 / \geq 10 \\
\text { genotype higher in IBS }\end{array}$ & No relation \\
\hline & & Park et $\mathrm{al}^{28}$ & Korea & $\begin{array}{l}>10 />10 \text { genotype higher } \\
\text { in IBS }\end{array}$ & $\begin{array}{l}>10 />10 \text { genotype in all IBS subtypes } \\
\text { higher than control }\end{array}$ \\
\hline TRPV1 & TRPV1 gene & Zhang et $\mathrm{al}^{27}$ & Gansu, China & $\mathrm{C} / \mathrm{C}$ and allele $\mathrm{C}$ higher in IBS & - \\
\hline
\end{tabular}

IBS, irritable bowel syndrome; SERT, serotonin transporter; 5-HTTLPR, serotonin transporter gene-linked polymorphic region; IBS-C, constipation predominant IBS; IBS-D, diarrhea predominant IBS; IBS-A, alternating IBS; PI-IBS, post-infectious IBS; VNTR, variable number tandem repeat; CNR1, cannabinoid receptor 1; TRPV1, transient receptor potential vanilloid type 1 .

dominantly higher than the frequencies of $\mathrm{L}$ allele and $\mathrm{L} / \mathrm{L}$ genotype. The result was similar to that in Korean and Japanese with this predominance, while different from that in Turkish,
European and American without this predominance. ${ }^{17}$ Therefore the racial difference may play a role in the gene polymorphism of IBS, although many other factors such as environment, habits 
and study designs could also influence the results. In addition, the gender difference probably also influenced the gene polymorphism, since $\mathrm{S} / \mathrm{S}$ genotype was found to be higher in female IBS-D patients ${ }^{4}$ and lower in male IBS-D patients ${ }^{15}$ than controls. The investigation by Sikander et $\mathrm{al}^{14}$ which showed S/S genotype was more common in IBS-C patients included more male patients, while the investigations in China which showed higher level of L/L genotype in IBS-C patients included more female patients. $^{6-10}$

Particularly, the polymorphism has been recently shown to be associated with the treatment response to the drug related to 5 -HT in patients with IBS. Smeraldi et $\mathrm{al}^{18}$ found that the effect of selective serotonin reuptake inhibitors (SSRIs) fluvoxamine was better for patients with $\mathrm{L} / \mathrm{L}$ and $\mathrm{L} / \mathrm{S}$ genotype than $\mathrm{S} / \mathrm{S}$ genotype. Camilleri et $\mathrm{al}^{3}$ reported that 5 -HT3 receptor antagonist alosetron was better for L/L genotype in IBS-D patients. $\mathrm{Li}$ et $\mathrm{al}^{8}$ showed that the effect of 5-HT4 agonist tegaserod was worst for $\mathrm{L} / \mathrm{L}$ genotype. These different pharmacologic responses might indicate that genetics influenced the effect of drugs on patients with IBS although the underlying reasons were unclear.

For VNTR region, most of the investigations in China ${ }^{8-10}$ and all of the investigations in other countries ${ }^{13,15}$ found no significant difference between IBS patients and healthy adults, also with no difference among the subtypes. But Wang et $\mathrm{al}^{6}$ found that STin2.12/10 genotype was more common in patients with IBS than healthy controls, and patients with IBS-C showed increased frequency of STin2 VNTR 12/12 and 5-HTTLPR L/L genotype (12/12-L/L) than controls and other subtypes. Chen et $\mathrm{al}^{7}$ showed similar result for post-infectious IBS (PI-IBS) patients. These 2 particular results may need further confirmation by more meticulous investigations with larger sample size.

IL-10 is an important anti-inflammatory cytokine in body. Therefore the genotype encoding low producer of IL-10 might be more prevalent in IBS patients since the infection and inflammation are always thought to be associated with IBS. Three well investigated regions for IL-10 were 1082, 819 and 592 loci in promoter. As mentioned in reports, $1082 \mathrm{~A}, 819 \mathrm{~T}$ and $592 \mathrm{~A}$ were the lower producer alleles for IL-10 compared to $1082 \mathrm{G}$, 819C and 592C respectively, so they might predict higher prevalence of IBS. ${ }^{19}$ Most studies showed IBS patients had higher frequency of low producer genotypes in these regions, which would lead to lower level of IL-10. Wang et $\mathrm{al}^{19}$ reported that IBS-D patients had higher frequency of low producer genotypes 819
T/T and $592 \mathrm{~A} / \mathrm{A}$ than healthy individuals. Higher frequency of low producer genotype 592A/A in patients with IBS overall was found in report of Jiang et al. ${ }^{20} \mathrm{~A}$ recent investigation in India reported patients with IBS overall had higher frequency of A allele in 592 locus, but no significant difference was found for alleles in 819 and 1082 loci and genotypes in these 3 regions. ${ }^{21}$ Different results also presented in the studies from the West. One study showed that the high producer 1082 G/G genotype was significantly lower in patients with IBS overall than controls. ${ }^{22}$ While another study found no relationship between overall or each subtype of IBS and the genotypes in 1082 and 819 loci. $^{23}$ These results suggested that the genetic alteration might contribute to the alteration of inflammatory cytokine level in some IBS patients, and thus affected the inflammatory state in these patients. In addition, there were several investigations reporting variation in genotypes regarding IL-10 according to ethnicity, with increased frequency of low producer genotype A/A or A allele in Chinese group than other population. ${ }^{24,25}$

Other 2 less investigated genes for IBS in China were associated with cannabinoid receptor $1(\mathrm{CNR} 1)^{26}$ and capsaicin receptor/transient receptor potential vanilloid type 1 (TRPV1). ${ }^{27}$ Since the cannabinoid could affect GI function, genetic variants for the CNR1 were hypothesized to be associated with pathogenesis of IBS. Zhang et $\mathrm{al}^{26}$ found that allele $\geq 10$ and $\geq 10$ / $\geq 10$ genotype for AAT triplet repeats in the 3-flanking region of CNR1 gene were significantly higher in patients with IBS than controls in Han population in Guangdong. Another investigation involving Korean subjects also showed the similar result and found that the patients with CNR1 $>10 />10$ genotype had more severe abdominal symptoms. ${ }^{28}$ The capsaicin receptor TRPV1 was estimated to be related with visceral pain and hypersensitivity states in IBS. The frequency of $\mathrm{C} / \mathrm{C}$ genotype and $\mathrm{C}$ allele for TRPV1 gene were both reported to be higher in patients with IBS than healthy individuals. ${ }^{27}$ These gene polymorphisms for CNR1 and TRPV1 may also be related to the susceptibility to IBS, which have not been reported in the West.

In conclusion, although the investigations of the gene polymorphism for IBS in China are limited, some of the results are different from those in other countries. The reason may be complex, and ethnicity and gender differences probably may somewhat correlate with it. More efforts are demanded to provide special data in China about candidate genes, which may contribute to future new therapy. 


\section{Disturbances of Gastrointestinal Motility}

Different results of GI motility measurements between IBS patients and healthy controls have been commonly reported in China (Table 2), which indicate that altered GI motility may contribute to the pathogenesis of IBS. The dysmotility of GI tract accounting for the symptoms of IBS is still in dispute. ${ }^{29}$ However the clinical investigations show the association between GI motility disturbances and bowel habits of different IBS subtypes. In general, the findings of parameters about gut motility suggested that the motility increased in IBS-D patients while decreased in IBS-C patients. From the aspect of GI transit time, all related studies in China showed that either the orocecal transit time or the total and each segmental colonic transit time was shorter in IBS-D patients and longer in IBS-C patients than healthy controls. ${ }^{30-32}$ The results were in agreement with those in many studies of other countries, although this correlation was not always consistent.

Disturbances of small bowel motility were widely reported in patients with IBS from various aspects in the world. In China, only the studies about discrete cluster contractions (DCC) and migrating motor complex (MMC) has been reported. The work by Wang and Zhao et $\mathrm{al}^{33,34}$ showed that patients with IBS-D exhibited shorter period for MMC, with prolonged duration proportion, greater amplitude, higher motility index and faster propagation velocity for the phase III of MMC than healthy controls, whereas patients with IBS-C exhibited the contrary alterations. Since phase III was important to the propagating movement of the intestine, the longer duration and greater amplitude of this phase was closely related to the symptom of diarrhea with quicker bowel movement. The duration of DCC in phase II was reported to be longer in patients with IBS than healthy controls, but no significant relationship between DCC and the episode of abdominal pain was found in Wang et al, ${ }^{33}$ while investigations in the West showed that the increased frequency and duration of DCC were associated with abdominal pain. ${ }^{29}$ Perhaps larger sample size was needed to clarify this result in China. Zhao et $\mathrm{al}^{34}$ also observed that the plasma motilin and 5-HT level were higher in IBS patients and fluctuated with the phase of MMC cycle, indicating the association of GI hormone and motility.

For colon motility, Liang et $\mathrm{al}^{35}$ reported that patients with IBS-D had stronger sigmoid colon motility, which represented as elevated wave amplitude and longer duration of high amplitude propagative bursts and higher $\mathrm{MI}$ at fasting state. Chen et $\mathrm{al}^{36}$ observed the motility of sigmoid colon by ultrasonography, and found that patients with IBS-D had more, while patients with IBS-C had less peristaltic contraction, whether at fasting or after meal. These 2 studies both reported that the patients with IBS-D had delayed but longer gastrocolic reflex after meal, which was not found in controls and patients with IBS-C. ${ }^{35,36}$ Most studies in other countries also showed the concordant results that there were more colonic motility in IBS-D patients while fewer in IBS-C patients. ${ }^{37,38}$

Upper GI symptoms were commonly seen in patients with IBS, and maybe these symptoms are somewhat correlated with the abnormal gastric motility. Our group investigated the accommodation and emptying of proximal stomach by real-time ultrasonography, and found that both the initial and maximal volumes of proximal stomach in IBS-D and IBS-C groups were lower than those in healthy group. This result indicated impaired accommodation of proximal stomach, which might induce higher pressure in stomach contributing to the dyspepsia symptoms such

Table 2. Studies on Gastrointestinal Motility Disturbances for Irritable Bowel Syndrome in China

\begin{tabular}{|c|c|}
\hline First author & Main finding \\
\hline Lu et $\mathrm{al}^{30}$ & Longer orocecal transit time in IBS-C patients while shorter in IBS-D patients \\
\hline Duan and Zhao ${ }^{31}$ & Longer total and each segmental colonic transit time in IBS-C patients \\
\hline Zhang et $\mathrm{al}^{39}$ & $\begin{array}{l}\text { Impaired accommodation and accelerated emptying of proximal stomach in IBS patients, with no significant difference between } \\
\text { IBS-D and IBS-C patients }\end{array}$ \\
\hline Wang et $\mathrm{al}^{33}$ & Shorter interdigestive MMC period, with prolonged duration, greater amplitude and faster propagation velocity for the phase III \\
\hline Zhao et $\mathrm{al}^{34}$ & of MMC in IBS-D patients, whereas contrary alterations in IBS-C patients; no association between DCC and abdominal pain \\
\hline Chen et $\mathrm{al}^{36}$ & $\begin{array}{l}\text { Increased peristaltic contraction and delayed gastrocolic reflex after meal in IBS-D patients; increased segmental movement but } \\
\text { decreased peristaltic contraction in IBS-C patients }\end{array}$ \\
\hline Liang et $\mathrm{al}^{35}$ & $\begin{array}{l}\text { Increased sigmoid colon motility at fasting state and delayed but longer gastrocolic reflex in IBS-D patients than controls and } \\
\text { IBS-C patients }\end{array}$ \\
\hline
\end{tabular}

IBS, irritable bowel syndrome; IBS-C, constipation predominant IBS; IBS-D, diarrhea predominant IBS; MMC, migrating motor complex; DCC, discrete clustered contraction. 
as early satiety and abdominal distention. ${ }^{39}$ The emptying of proximal stomach in IBS patients was recorded to be accelerated, which may also be correlated with the higher pressure of stomach in IBS patients. ${ }^{39}$ However, delayed gastric emptying in IBS patients have been shown in many studies of other countries, ${ }^{40-42}$ especially in patients with dyspepsia symptoms ${ }^{40}$ or IBS-C patients. ${ }^{42}$ The variation of results between China and other countries may be caused by the different test methods and trial designs.

To summarize, various disturbances of GI motility have been found in different subgroups of IBS patients, which are likely to play an important role in bowel habits of IBS. There are still a few conflicting results found between China and other countries, and further confirmatory work is needed in China to get the truth.

\section{Visceral Hypersensitivity}

Visceral hypersensitivity has been commonly reported as a pathophysiologic factor for IBS in recent years, which may play a role in the symptoms of IBS especially abdominal pain. Many studies have shown higher sensitivity to rectal balloon distention in IBS patients in China (Table 3). Most of the studies reported that the initial perception thresholds, defecation thresholds and pain thresholds were much lower in IBS-D patients than those in healthy volunteers. ${ }^{43-46}$ But different from the consistent result in patients with IBS-D, there was still controversy for patients with IBS-C. Dong and Li et al ${ }^{43,47}$ reported that patients with IBS-C had lower initial perception, defecation and pain thresholds than healthy controls; Xiao and Shen et $\mathrm{al}^{45,46}$ reported no significant difference compared with controls; Li's group and Zhan et al ${ }^{32,44}$ reported lower initial perception thresholds in IBS-C patients than controls without significance, but significantly higher defecation thresholds than controls; Yang et $\mathrm{al}^{48}$ even reported higher perception, defecation and pain thresholds than controls. Chen et $\mathrm{al}^{49}$ showed that the perception thresholds of IBS patients were lower than controls with quick dilation test but no significant difference was noted on the slow dilation test. In conclusion, most of these researches above suggested higher sensation feeling in IBS-D patients and related lower sensation in IBS-C patients, and the method of dilatation might have influenced the results.

Similar to the results in China, many studies in other countries also reported decreased sensory thresholds to rectal distension in IBS patients. Moreover, enhanced perceptions to visceral stimulation were also reported in other regions of the GI tract in other countries. However, not all of the investigations showed identical results. The results for sensory thresholds were also found to be different among the investigations measured by different distension methods in the West, with lower thresholds for rapid phasic distensions than slow ramp distensions. ${ }^{50}$ In addition, IBS-D patients were reported to be more sensitive than IBS-C patients and the different results for IBS-C patients also existed in the studies from other countries. In these studies, less, equal or higher sensitivities corresponding to rectal distension in IBS-C patients compared to healthy subjects have been reported. $^{51}$ The different results for IBS-C patients may be related to the long-term high pressure of rectum for some patients with constipation and the variability among these patients such as dietary fiber intakes and other managements.

The sensation and related symptoms of IBS patients in respond to other stimulations aside from pressure stimulus have also been reported in China. Li's group ${ }^{44}$ found that the initial and defecation thresholds responding to rectal distension in IBS patients decreased significantly after ice-water injected into balloon, especially in IBS-D patients, while cold stimulation on abdomen did not affect the thresholds although it could have induced the symptoms of IBS. This investigation indicated that hypersensitivity was also related to thermal stimulation and might have been limited to the viscera. ${ }^{44}$ Another study by them reported that the initial perception and defecation thresholds decreased after ice water drinking in IBS-D patients, which were negatively related to the symptoms. ${ }^{52}$ These results above suggested visceral hypersensitivity to mechanical and temperature stimulation might exist in IBS patients, and the altered sensitivity correlated with abdominal symptoms. Although it remains controversial whether somatic sensory dysfunction exists in IBS for different results in various studies worldwide, most studies tend to report no significant relationship between somatic sensitivity and IBS patients. $^{51,53}$ Lots of investigations in other countries have also displayed the altered visceral sensitivity correlating with GI symptom severity of IBS, despite some conflicting results.

The altered cerebral response to rectal balloon distension has been shown in patients with IBS assessed by various techniques in most studies worldwide. In China, the cerebral responses assessed by methods of functional magnetic resonance imaging (fMRI) and cerebral evoked potentials (CEP) have been reported (Table 3). Yuan et $\mathrm{al}^{54}$ showed both IBS patients and controls to present exaggerated activity at the regions of anterior cingulate cortex, insula, prefrontal cortex and thalamus by fMRI during rectal distension, while IBS patients showed enhanced activation in insula, prefrontal cortex and thalamus than controls. They also found that IBS patients had more severe pain respond- 
Table 3. Studies on Visceral Hypersensitivity for Irritable Bowel Syndrome in China

\begin{tabular}{|c|c|c|}
\hline Targets & First author & Main findings \\
\hline \multirow{8}{*}{$\begin{array}{l}\text { Intestinal sensory } \\
\text { response to rectal } \\
\text { distention }\end{array}$} & Dong et $\mathrm{al}^{43}$ & Lower initial perception, defecation and pain thresholds in IBS-D and IBS-C patients than controls \\
\hline & Xiao et $\mathrm{al}^{45}$ & $\begin{array}{l}\text { Lower initial perception, defecation and pain thresholds in IBS-D patients than IBS-C patients and controls; } \\
\text { no significant difference between IBS-C patients and controls }\end{array}$ \\
\hline & Shen et $\mathrm{al}^{46}$ & $\begin{array}{l}\text { Lower defecation threshold in IBS-D patients than IBS-C patients and controls; no significant difference } \\
\text { between IBS-C patients and controls }\end{array}$ \\
\hline & Li et $\mathrm{al}^{47}$ & Lower perception, defecation and pain thresholds in IBS-C patients than controls \\
\hline & Zhan et $\mathrm{al}^{32}$ & $\begin{array}{l}\text { Lower initial perception threshold in IBS-C patients than controls without significance, but significantly higher } \\
\text { defecation threshold than controls }\end{array}$ \\
\hline & Yang et $\mathrm{al}^{48}$ & $\begin{array}{l}\text { Lower initial perception, defecation and pain thresholds in IBS-D patients but higher in IBS-C patients than } \\
\text { controls }\end{array}$ \\
\hline & Li et $\mathrm{al}^{44}$ & $\begin{array}{l}\text { Lower initial perception and defecation thresholds in IBS-D and IBS-A patients, which decreased after ice } \\
\text { water injection; lower initial perception threshold but higher defecation threshold in IBS-C patients }\end{array}$ \\
\hline & Zuo et $\mathrm{al}^{52}$ & $\begin{array}{l}\text { Decreased initial perception and defecation threshold after ice water drinking in IBS-D patients with negative, } \\
\text { linear correlation to symptoms }\end{array}$ \\
\hline \multirow[t]{2}{*}{ Cerebral response } & Zuo et $\mathrm{al}^{55}$ & $\begin{array}{l}\text { Shorter N1, P1, N2 latencies of CEP by rectal distention in IBS patients than controls, which decreased after } \\
\text { ice water drinking }\end{array}$ \\
\hline & $\begin{array}{l}\text { Shen et } \mathrm{al}^{46} \\
\text { Yuan et } \mathrm{al}^{54}\end{array}$ & Increased activation at insula, prefrontal cortex and thalamus in IBS patients to rectal distention than controls \\
\hline \multirow[t]{12}{*}{ MCs and 5-HT } & Dong et $\mathrm{al}^{43}$ & $\begin{array}{l}\text { MCs at terminal ileum, ICJ, ascending colon, and VIP and SP positive nerve fibers increased in IBS patients; } \\
\text { MCs were close to unmyelinated nerves and plasma cells }\end{array}$ \\
\hline & Wang et al ${ }^{57}$ & $\begin{array}{l}\text { MCs at terminal ileum increased in IBS patients and closely surrounded NSE, SP, 5-HT and CGRP positive } \\
\text { nerve fibers }\end{array}$ \\
\hline & Wang et $\mathrm{al}^{58}$ & $\begin{array}{l}\text { MCs at the terminal ileum increased in IBS patients; 5-HT at the proximal jejunum decreased in IBS-C } \\
\text { patients }\end{array}$ \\
\hline & Yang et $\mathrm{al}^{59}$ & MCs at ICJ increased in the IBS patients \\
\hline & Chen et $\mathrm{al}^{60}$ & $\begin{array}{l}\text { MCs at ICJ, TRPV1 at sigmoid colon, SP at both sites increased in IBS patients, without significant difference } \\
\text { between IBS-D and IBS-C; TRPV1 positively correlated with abdominal pain }\end{array}$ \\
\hline & Wang et $\mathrm{al}^{62}$ & $\begin{array}{l}\text { MCs at cecum and transverse colon increased in IBS-D patients; degranulated MCs percentage in cecum, } \\
\text { transverse colon and rectum mucosa of IBS-D patients, which were higher than controls and IBS-C patients }\end{array}$ \\
\hline & Wang et $\mathrm{al}^{63}$ & Number and activity of MCs at rectosigmoid junction increased in IBS, correlating with symptom severity \\
\hline & Chen et $\mathrm{al}^{61}$ & $\begin{array}{l}\text { MCs and degranulated MCs percentage at ICJ increased in IBS patients, which was higher in IBS-D than } \\
\text { IBS-C patients; } 5 \text {-HT concentration at ICJ increased in IBS patients, with no significant difference between } \\
\text { IBS-D and IBS-C patients }\end{array}$ \\
\hline & Li et $\mathrm{al}^{64}$ & 5-HT positive cells and 5- $\mathrm{HT}_{3}$ receptor in all sections of colon increased in IBS-D patients than controls \\
\hline & Li et $\mathrm{al}^{65}$ & Number and activity of EC cells increased in IBS patients \\
\hline & Zhan et al ${ }^{66}$ & $\begin{array}{l}\text { 5-HT and 5-HIAA levels in plasma were lower at remission than active stage in IBS patients, which remained } \\
\text { higher than controls; 5-HT level was higher in IBS-D than IBS-C patients at active but not remission stage }\end{array}$ \\
\hline & Zuo et $\mathrm{al}^{67}$ & $\begin{array}{l}\text { 5-HT and 5-HIAA levels in plasma were higher in IBS-D patients than controls after ice water intake, but no } \\
\text { significant difference at fasting stage }\end{array}$ \\
\hline
\end{tabular}

IBS, irritable bowel syndrome; IBS-D, diarrhea predominant IBS; IBS-C, constipation predominant IBS; IBS-A, alternating IBS; CEP, cerebral evoked potentials; MCs, mast cells; 5-HT, 5-hydroxytryptamine; ICJ, ileocecal junction; VIP, vasoactive intestinal polypeptide; SP, substance P; NSE, neuron-specific enolase; CGRP, calcitonin gene-related peptide; TRPV1, transient receptor potential vanilloid type 1; EC, enterochromaffin; 5-HIAA, 5-hydroxyindoleacetic acid.

ing to rectal distention than controls, which supported the association between the altered cerebral response and pain perception in IBS patients. ${ }^{54} \mathrm{Zuo}$ et al ${ }^{55}$ recorded the CEP to rectal balloon distension and then found specific latencies of CEP to be decreased in IBS patients with shorter CEP after ice water intake. The result suggested the role of visceral hypersensitivity and defects in visceral afferent pathway. ${ }^{55}$ Despite contradictory results presented among different studies worldwide, most of them suggested differences existed between IBS patients and healthy controls in the response of brain during gut stimulation. Although the activated cerebral regions in respond to rectal distension varied in different reports, a meta-analysis showed IBS patients had 
consistently greater activations in the regions related to pain modulation and emotional arousal than controls by collecting researches with fMRI or positron emission tomography techniques. It was supposed that disturbances in central nervous system processing might have been involved in the pathophysiology of IBS. $^{56}$

Neurohumoral abnormalities have been identified in IBS patients with visceral hypersensitivity, of which mast cells (MCs) and 5-HT were most commonly reported. The MCs in gut including terminal ileum, ${ }^{43,57,58}$ ileocecal junction, ${ }^{43,59-61}$ cecum, ${ }^{60}$ ascending colon, ${ }^{43}$ transverse colon ${ }^{62}$ and rectosigmoid junction ${ }^{63}$ have been reported to increase in IBS patients compared with health controls (Table 3 ). Dong et $\mathrm{al}^{43}$ also reported apparent variation of MCs existing in IBS patients. The expression of certain transmitters and neuropeptides such as substance $\mathrm{P}$, neuron-specific enolase, calcitonin gene-related peptide and 5-HT were reported to be elevated in IBS patients. The nerve fibers with the positive expression of these substances were found to surround MCs closely, which indicated that MCs might play an important role in pathophysiology of IBS through the connection of nerve and immune systems. ${ }^{43,57}$ Furthermore, Chen et $\mathrm{al}^{61}$ and our group ${ }^{62}$ both reported the percentage of degranulated MCs in IBS patients which was higher than controls, and this percentage was significantly higher in IBS-D patients than that in IBS-C patients. The concentration of 5-HT and the number and activity of EC cells in colonic mucosa were always found to be elevated in IBS patients. ${ }^{61,64,65}$ But Wang et al $^{58}$ showed variant levels of 5-HT in different parts of small intestine, with significantly lower level of 5-HT in the proximal jejunum. For 5-HT and 5-hydroxyindoleacetic acid (5-HIAA) level in plasma, Zhan ${ }^{66}$ reported significantly higher level in patients with IBS than controls whether at the active or remission stage, while Zuo et al $^{67}$ reported higher level in IBS-D patients than controls after ice water drinking but not at fasting state. However, whether difference existed in the expression of MCs and 5-HT in IBS-D and IBS-C patients was controversial. Some studies reported higher level in IBS-D than IBS-C patients, while others reported no significant difference between them. ${ }^{60-64}$ In addition, the activation percentage of MCs and 5-HT level were reported to be positively correlated with severity of symptoms. ${ }^{63,67}$ TRPV 1 was also shown to be positively related to the score of abdominal pain. ${ }^{60}$ These studies about relationship between symptoms of IBS and immunity materials associated with sensitivity may further support the mechanism of visceral hypersensitivity in IBS.

In general, visceral hypersensitivity is involved in both the gut and brain in IBS patients and probably contributes to the symptoms of these patients. The underlying mechanisms of hypersensitivity have not been clear yet, but MCs and 5-HT are probably involved.

\section{Intestinal Infection and Inflammation}

Intestinal infection has been considered as an important pathogenic factor in IBS, which may cause related bowel symptoms in a short period defined as PI-IBS. Many epidemiologic studies in China exhibited that the infection of dysentery was an independent risk factor for IBS. ${ }^{68,69}$ A cohort study in Beijing followed up patients after intestinal infection and healthy persons who had no previous history of functional bowel disorder. About $8.1 \%$ of individuals with intestinal infection and $10.2 \%$ of those with Shigella infection were found to develop IBS in the 2-yearperiod compared to only $0.8 \%$ in controls. ${ }^{70}$ The incidence of PI-IBS has been reported to vary from $4 \%$ to $32 \%$ worldwide in a meta-analysis, with most about $10 \%$, which was significantly higher than the IBS incidence in control group without infection. ${ }^{71}$ Although intestinal infection was not specific for an area or a race, the types of microorganism infected on IBS patients were somewhat regional specific. Infections of Salmonella and Campylobacter were always reported in the West, ${ }^{71}$ while Shigella seemed to be a more usual bacterium in China and Korea from Asia. ${ }^{70,72}$ In Pakistan, Blastocystis hominis has been shown to be more common in IBS patients than healthy controls. ${ }^{73}$ Although infections of parasites such as Giardia lamblia were common in some areas of Asia like India, there were few studies reporting their association with IBS in Asia. ${ }^{74}$ The different types of infected microorganism may be associated with the different resident environment and diet habits.

There were a lot of investigations suggesting the role of inflammation and immunity activation for IBS in China, most presenting as the alteration of lymphocytes and cytokines (Table 4). Although conflicting results existed, decreased CD4/CD8 lymphocytes ratio was reported in IBS patients compared with controls. ${ }^{75,76}$ Most investigations showed the immunity alteration in IBS patients with significantly higher level of proinflammatory cytokines (IL-1 $\beta,{ }^{77}$ IL-2, ${ }^{78}$ IL-6, ${ }^{79}$ IL-8, ${ }^{80}$ IL-12, ${ }^{81}$ IL-18, ${ }^{79}$ TNF- $\alpha,{ }^{80}$ IFN- $\gamma^{78,81}$ ) and lower level of anti-inflammatory cytokines (IL-4, ${ }^{82}$ IL-10 ${ }^{82,83}$ ), whether in peripheral blood or in intestinal mucosa. A study from Taiwan involving children suggested anti-inflammatory cytokine IL-10 to negatively correlate with abdominal pain intensity, ${ }^{83}$ implying the correlation between immune alteration and symptoms. Wu and $\mathrm{Li}$ et $\mathrm{al}^{81,82}$ reported 
Table 4. Studies on Inflammation for Irritable Bowel Syndrome in China

\begin{tabular}{|c|c|c|c|}
\hline Targets & First author & Region & Main findings \\
\hline \multirow[t]{3}{*}{ Lymphocytes } & Linghu and Yang ${ }^{75}$ & Peripheral blood & $\begin{array}{l}\text { Decreased CD4+ and increased CD8 }+\mathrm{T} \text { lymphocytes with decreased } \\
\mathrm{CD} 4 / \mathrm{CD} 8 \text { ratio in IBS patients }\end{array}$ \\
\hline & Yang et $\mathrm{al}^{76}$ & Peripheral blood & $\begin{array}{l}\text { Decreased CD4+ and increased CD8 + T lymphocytes with decreased } \\
\text { CD4/CD8 ratio in IBS-D patients; decreased CD4+ and CD8 }+\mathrm{T} \\
\text { lymphocytes with increased CD4/CD8 ratio in IBS-C patients }\end{array}$ \\
\hline & Fu et $\mathrm{al}^{84}$ & $\begin{array}{l}\text { Intestinal mucosa/ } \\
\text { Peripheral blood }\end{array}$ & $\begin{array}{l}\text { Increased Th17 cells in colonic mucosa of IBS-D patients with nonspecific } \\
\text { microscopic inflammation, but not in mucosa without inflammation and } \\
\text { peripheral blood }\end{array}$ \\
\hline \multirow[t]{7}{*}{ Cytokines } & Zhang et a ${ }^{80}$ & Peripheral blood & $\begin{array}{l}\text { Higher IL- } 8 \text { level in IBS-D patients, which positively correlated with TNF- } \alpha \\
\text { level, but not found in IBS-C patients }\end{array}$ \\
\hline & Liang et $\mathrm{al}^{79}$ & Peripheral blood & $\begin{array}{l}\text { Higher IL-6 and IL-18 level in IBS-D patients; higher IL-18 level IBS-C } \\
\text { patients; infection up-regulated IL-6 and IL-18 level }\end{array}$ \\
\hline & Hua et $\mathrm{al}^{83}$ & Peripheral blood & Lower IL-10 level in IBS children, which negatively correlated with pain intensity \\
\hline & Ju et $\mathrm{al}^{78}$ & Intestinal mucosa & Higher IL-2 and IFN- $\gamma$ level in colonic and rectal mucosa in IBS-D patients \\
\hline & Song et $\mathrm{al}^{77}$ & Intestinal mucosa & Higher IL-1 $\beta$ level at ICJ mucosa in IBS patients \\
\hline & Wu et al ${ }^{82}$ & Peripheral blood & $\begin{array}{l}\text { Significantly lower Th2-type cytokine level of IL- } 4 \text { and IL- } 10 \text { and relatively } \\
\text { higher Th1-type cytokine level of IL-12 and IFN- } \gamma \text { in IBS-D patients, but not } \\
\text { in IBS-C patients }\end{array}$ \\
\hline & Li et al ${ }^{81}$ & Intestinal mucosa & $\begin{array}{l}\text { Significantly higher Th1-type cytokine level of IL-12 and IFN- } \gamma \text { and relatively } \\
\text { lower Th2-type cytokine level of IL- } 4 \text { and IL- } 10 \text { in IBS-D patients }\end{array}$ \\
\hline \multirow[t]{4}{*}{ Cytokines (PI-IBS) } & Wu et al ${ }^{82}$ & Peripheral blood & $\begin{array}{l}\text { Higher level of IFN- } \gamma \text { and lower level of IL-4 and IL-10 in post-infectious IBS-D } \\
\text { patients, but not in those without infection }\end{array}$ \\
\hline & Li et al ${ }^{81}$ & Intestinal mucosa & $\begin{array}{l}\text { Higher level of IL-12 and IFN- } \gamma \text { in post-infectious IBS-D patients, but not in } \\
\text { those without infection }\end{array}$ \\
\hline & Ju et $\mathrm{al}^{78}$ & Intestinal mucosa & $\begin{array}{l}\text { SP in PI-IBS patients with positive expression of IL-2 and IFN- } \gamma \text { higher than that } \\
\text { in non-PI-IBS patients and controls }\end{array}$ \\
\hline & Wang et $\mathrm{al}^{70}$ & Intestinal mucosa & $\begin{array}{l}\text { Higher IL- } 1 \beta \text { mRNA expression in terminal ileum and recto-sigmoid junction in } \\
\text { PI-IBS patients than non-PI-IBS patients and controls }\end{array}$ \\
\hline
\end{tabular}

IBS, irritable bowel syndrome; IBS-C, constipation predominant IBS; IBS-D, diarrhea predominant IBS; ICJ, ileocecal junction; PI-IBS, post-infectious IBS; SP, substance $\mathrm{P}$.

IBS-D patients had higher Th1-type cytokine level and lower Th2-type cytokine level in peripheral blood and intestinal mucosa. ${ }^{2}$ Our group measured the Th1/Th2/Th17 level in peripheral blood and colonic mucosa for IBS-D patients, and showed Th17 proportion to be increased only in colonic mucosa with nonspecific microscopic inflammation, but not in the mucosa without inflammation and peripheral blood. There was no significant change for the Th1, Th2 and associated cytokines between IBS patients and controls in either colonic mucosa or peripheral blood. ${ }^{84}$ Moreover, PI-IBS patients were always found to have more severe inflammation than non-PI-IBS patients and healthy controls in China (Table 4). ${ }^{70,78,81,82}$ It indicated that the role of intestinal infection for the pathogenesis of IBS probably acted through some immunological changes.

The underlying mechanisms of PI-IBS have not been clearly identified worldwide. Persistent mucosal inflammation and im- mune activation, manifested as increased lymphocytes, MCs, EC cells and inflammatory cytokines have been commonly reported in the West. ${ }^{85}$ Similar to the results in China, there is also a trend toward higher level of proinflammatory cytokines and lower level of anti-inflammatory cytokines found in the investigations of other countries, although some conflicting results exist. Whether Th1-type or Th2-type profile is presented in IBS patients is still controversial with the contradictory results from different studies in the West. ${ }^{86}$ Different from the results on lymphocytes in China, increased level of CD4+ and CD8 $+\mathrm{T}$ lymphocytes has always been reported in intestinal mucosa of IBS patients, while regular level was reported in peripheral blood. ${ }^{87}$ The reasons for these different results are unclear, therefore additional investigations are needed. Anyway, all these studies above indicated that intestinal infection and inflammation might take part in the pathophysiology of IBS through immunological mechanism. 


\section{Food Hypersensitivity and Intolerance}

Many patients with IBS always complained of their bowel symptoms relating to meal, implying some association between IBS and food. Although diet ingestion could affect symptoms through various pathways, ${ }^{88}$ food hypersensitivity and intolerance were still considered as possible pathophysiologic factors for IBS. There were many studies reporting the levels of food-specific IgE and IgG antibodies in serum and the effectiveness of food elimination in China. Most studies reported that the levels of food-specific IgG antibody were higher in IBS patients than healthy controls. ${ }^{89-92} \mathrm{Zuo} \mathrm{et} \mathrm{al}^{90}$ reported the serum IgG antibody titers of specific foods including shrimp, crab, soybean, egg and wheat, which were higher in patients with IBS, but there was no obvious association found between the IgG antibody titers and symptom severity. Zhang et $\mathrm{al}^{89}$ showed that the frequency and severity of symptoms of IBS were obviously decreased in patients after eliminating intolerant foods based on $\mathrm{IgG}$ antibody for 8 weeks. In the West, many studies have also displayed that serum IgG antibody levels were elevated in IBS patients, ${ }^{93}$ and food elimination diets for the patients with increased IgG antibody to specific food antigens could help to reduce symptoms. ${ }^{94}$ A systematic review of 7 clinical trials showed a $15 \%-71 \%$ response rate to diet exclusion, and the most commonly incriminated foods included milk, wheat and eggs. ${ }^{95}$

Different from the IgG antibody, there is controversy for the results of food-specific IgE antibody in China. $\mathrm{Xu}$ and $\mathrm{Zhu}{ }^{91}$ reported higher positive rate of food-specific $\mathrm{IgE}$ antibody in IBS patients than healthy individuals. Yang and $\mathrm{Li}^{92}$ showed higher positive rate in IBS-D patients than controls, but not in IBS-C patients. No significant difference was found for food- specific and total IgE titers between IBS patients and healthy controls in another study by Zuo et al. ${ }^{90}$ In the West, food-specific IgE level had been evaluated as one of the markers for food hypersensitivity, ${ }^{88}$ and there was little evidence for the role of $\mathrm{IgE}$ mediated immediate phase reaction in IBS. ${ }^{96}$

Therefore most studies supported the role of food hypersensitivity and intolerance in IBS, and diet exclusion based on IgG might be effective for treatment of IBS patients with elevated $\mathrm{IgG}$ level. However further investigations are needed to clarify the mechanisms underlying food hypersensitivity and intolerance, and find more effective treatments for the patients with these problems.

\section{Psychological Disturbances}

Psychological disturbances occur commonly in IBS patients from both the Western or Eastern studies. Although psychological factor might not be the cause of IBS, it always correlated with the aggravation of symptoms. In China, many epidemiologic investigations showed that the IBS patients had more psychological problems. ${ }^{6197-101}$ A hospital-based investigation conducted in 3 metropolises in China reported one quarter of patients with IBS had depressive or anxiety symptoms. ${ }^{97}$ A recent large-scale study for undergraduates in Shandong province reported the score of depression and anxiety by hospital anxiety and depression scale was higher in undergraduates diagnosed as IBS than healthy controls. ${ }^{98}$ Our group also got the similar result for undergraduates in Wuhan. ${ }^{99}$ Lee et $\mathrm{al}^{100}$ showed IBS was closely related to generalized anxiety disorder in a community study of Hong Kong. Chen et $\mathrm{al}^{61}$ found IBS patients who had more psychological disturbance showed the increased number and degranulation of MCs in mucosa, implying the association between psychology and mucosal immunity alteration. Wang's group ${ }^{101}$ reported that IBS patients paid more attention to GI symptoms and up-regulated visceral sensation under the stimulus of uncomfortable pictures about digestive diseases, which were relieved by diverting attention. Then this research not only showed the psychological disturbances in IBS patients but also displayed the effect of psychological factor on visceral hypersensitivity. In other studies, they showed the IBS patients had more negative life events and inappropriate coping styles, ${ }^{102}$ and proposed the effectiveness of cognitive therapy for the patients with refractory IBS. ${ }^{103}$ There were also many other studies reporting that psychotherapy was effective in the treatment of IBS, ${ }^{104}$ which further supported that psychological factors played a role in pathogenesis of IBS. The association between IBS and psychological disturbances has also been commonly reported in other countries. On the whole, psychological disturbances have been shown to be associated with IBS, but whether it is a pathophysiologic factor for IBS is still not certain. Hence much effort should be done to clarify the true relation between them and find out the underlying mechanisms.

\section{Altered Gut Microflora}

It has been noticed that intestinal infection was related to IBS and antibiotics could affect digestive symptoms, which may indicate the role of gut microflora in IBS. There were many studies reporting the changes in intestinal microflora in IBS patients and 
the effectiveness of probiotics for them in China. An early study of our group examined 9 kinds of common microflora in feces, and showed that the number of Bacteroides, Bifidobacterium and Enterobacteria decreased in patients with IBS-D compared with that in healthy controls. ${ }^{105} \mathrm{Si}$ et al ${ }^{106}$ found IBS patients had decreased number of Bifidobacterium and increased number of Enterobacteriaceae. The microbial colonization resistance, calculated as the ratio of Bifidobacterium to Enterobacteriaceae (B/E ratio), was significantly lower in IBS patients $(<1)$ than that in controls $(>1)$, indicating impairment of colonization resistance and increased susceptibility to pathogenic bacteria overgrowth in IBS patients. ${ }^{106}$ Chen et al ${ }^{107}$ got the similar result for IBS-D patients, and they also reported decreased number of Lactobacillus and increased number of Saccharomycete. Zhang ${ }^{108}$ found significantly decreased number of anaerobic flora and increased number of aerobic flora in IBS patients and the dysbacteria state was different in distinct subtypes. However, the number of Bifidobacterium and Lactobacillus was always decreased in all subtypes of IBS to varying degrees. ${ }^{108}$

Although the results were different in various studies, most of the studies from China reported decreased level of Bifidobacterium and Lactobacillus in IBS patients. Therefore targeted supplement of probiotics containing these floras might be an effective therapeutic pathway. The benefits of probiotics to the improvement of IBS symptoms have been commonly reported in numerous studies in China. ${ }^{109-112}$ A multi-center, double-blind, randomized controlled trial exhibited the effect of Bifidobacterium for symptom improvement in IBS-D patients which was better than placebo group in all stages of the treatment. ${ }^{109} \mathrm{Zhu}$ et al ${ }^{110} \mathrm{com}-$ pared the total and each symptom scores for IBS-D patients before and after the treatment with Medilac-S (Bacillus subtilis and Enterococcus faecium) and BIFICO (Bifidobacterium longum, Lactobacillus acidophilus and Enterococcus), and showed the benefits of them. An open-label trial by Fan et $\mathrm{al}^{111}$ reported that treatment with probiotics comprising Bifidobacterium, Lactobacillus and Enterococcus could regulate the balance of microorganism in intestine and relieved the bowel symptoms of IBS. Zeng et $\mathrm{al}^{112}$ showed treatment with active lactic acid bacteria, which decreased the mucosal permeability of small bowel and achieved symptom improvement in IBS-D patients. The result implied that microflora imbalance contributed to bowel symptoms of IBS through a pathway of changing the mucosal permeability. ${ }^{12}$ To conclude, all these clinical studies in China showed that there was gut microflora alteration in patients with IBS and the treatment with probiotics probably improved the IBS symptoms by modulating the microorganism environments.

In the West, there were also a large amount of investigations exploring the microorganism states in IBS patients and the effects of different kinds of probiotics for patients. These researches didn't exhibit concordant alterations of microflora among all IBS patients, while different microflora composition was found in different subtypes. ${ }^{113}$ The underlying mechanisms for the role of microflora imbalance in IBS have not been clearly identified. Perhaps higher level of organic acid and excessive gas caused by altered intestinal flora, which was found to correlate with GI symptoms, would play a role in the pathophysiology of IBS. ${ }^{113}$ The therapeutic effect of probiotics varied in different studies for different strains chosen and trial designs. But a meta-analysis of these studies confirmed the benefit of probiotics in the treatment of IBS. ${ }^{114}$ However, probiotics cannot be effective for all IBS patients, so further work is deserved to identify the patient groups which can get most benefit from it and to choose the most appropriate and effective strains.

\section{Conclusion}

The factors discussed above have been displayed to be associated with the pathophysiology of IBS. Although most of the results of related investigations in China were similar to the Western and other Eastern countries, it was needed to pay more attention that some conflicting outcomes existed in China. Since IBS is a heterogeneous disorder, it is probable that more than one mechanism to be presented in a specific patient and these particular mechanisms are involved in different patients to various extents. IBS still remains a complicated and inadequately understood disease. So much effort is needed in future to get a better understanding about the pathophysiology for symptom generation and to develop more effective and appropriate therapy for IBS.

\section{References}

1. Gwee KA, Bak YT, Ghoshal UC, et al. Asian consensus on irritable bowel syndrome. J Gastroenterol Hepatol 2010;25:1189-1205.

2. Saito YA. The role of genetics in IBS. Gastroenterol Clin North Am 2011;40:45-67.

3. Camilleri M, Atanasova E, Carlson PJ, et al. Serotonin-transporter polymorphism pharmacogenetics in diarrhea-predominant irritable bowel syndrome. Gastroenterology 2002;123:425-432.

4. Yeo A, Boyd P, Lumsden S, et al. Association between a functional polymorphism in the serotonin transporter gene and diarrhoea predominant irritable bowel syndrome in women. Gut 2004;53:14521458 . 
5. Park JM, Choi MG, Park JA, et al. Serotonin transporter gene polymorphism and irritable bowel syndrome. Neurogastroenterol Motil 2006;18:995-1000.

6. Wang BM, Wang YM, Zhang WM, et al. Serotonin transporter gene polymorphism in irritable bowel syndrome. Zhonghua Nei Ke Za Zhi 2004;43:439-441.

7. Chen YB, Zhang BL, Zhang XY, Liu FT, Wu AC. Relationship of IBS and SERT polymorphism after intestinal infection. Modern Hospital 2010;10:11-13.

8. Li YY, Nie YQ, Xie J, Tan HZ, Zhou YJ, Wang H. Serotonin transporter gene polymorphisms in irritable bowel syndrome and their impact on tegaserod treatment. Zhonghua Nei Ke Za Zhi 2006; $45: 552-555$.

9. Xie J, Zhang ZX, Huang CB, Shu T, Wu XJ. Serotonin transporter gene polymorphism in constipation-predominant irritable bowel syndrome. J Gannan Med Univ 2008;28:484-486.

10. Zhang XM, Lin ZH. Relationship between serotonin transporter gene polymorphisms and irritable bowel syndrome. World J Gastroenterol 2006;14:1790-1794.

11. Lee DY, Park H, Kim WH, Lee SI, Seo YJ, Choi YC. Serotonin transporter gene polymorphism in healthy adults and patients with irritable bowel syndrome. Korean J Gastroenterol 2004;43:18-22.

12. Kim HJ, Camilleri M, Carlson PJ, et al. Association of distinct alpha(2) adrenoceptor and serotonin transporter polymorphisms with constipation and somatic symptoms in functional gastrointestinal disorders. Gut 2004;53:829-837.

13. Pata C, Erdal ME, Derici E, Yazar A, Kanik A, Ulu O. Serotonin transporter gene polymorphism in irritable bowel syndrome. Am J Gastroenterol 2002;97:1780-1784.

14. Sikander A, Rana SV, Sinha SK, et al. Serotonin transporter promoter variant: analysis in Indian IBS patients and control population. J Clin Gastroenterol 2009;43:957-961.

15. Niesler B, Kapeller J, Fell C, et al. 5-HTTLPR and STin2 polymorphisms in the serotonin transporter gene and irritable bowel syndrome: effect of bowel habit and sex. Eur J Gastroenterol Hepatol 2010;22:856-861.

16. Van Kerkhoven LA, Laheij RJ, Jansen JB. Meta-analysis: a functional polymorphism in the gene encoding for activity of the serotonin transporter protein is not associated with the irritable bowel syndrome. Aliment Pharmacol Ther 2007;26:979-986.

17. Xie J, Li YY, Nie YQ, Liang PZ, Zhang L. Serotonin transporter gene polymorphism in healthy adults and patients with irritable bowel syndrome. Acad J Guangdong Med College 2005;33:1-4.

18. Smeraldi E, Zanardi R, Benedetti F, Di Bella D, Perez J, Catalano M. Polymorphism within the promoter of the serotonin transporter gene and antidepressant efficacy of fluvoxamine. Mol Psychiatry 1998;3:508-511.

19. Wang BM, Jiang XZ, Yang YL, Liu WT, Cao XC, Zhao XZ. A study of interleukin-10 gene polymorphism in irritable bowel syndrome. Zhonghua Nei Ke Za Zhi 2006;45:289-292.

20. Jiang YJ, Nie YQ, Lai XB. IL-10 gene promoter-592 polymorphism and irritable bowel syndrome. Modern Hospital 2010;10: 8-10.

21. Santhosh S, Dutta AK, Samuel P, Joseph AJ, Ashok Kumar J, Kurian G. Cytokine gene polymorphisms in irritable bowel syndrome in Indian population - a pilot case control study. Trop
Gastroenterol 2010;31:30-33.

22. Gonsalkorale WM, Perrey C, Pravica V, Whorwell PJ, Hutchinson IV. Interleukin 10 genotypes in irritable bowel syndrome: evidence for an inflammatory component? Gut 2003;52:91-93.

23. Van der Veek PP, van den Berg M, de Kroon YE, Verspaget HW, Masclee AA. Role of tumor necrosis factor-alpha and interleukin-10 gene polymorphisms in irritable bowel syndrome. Am J Gastroenterol 2005;100:2510-2516.

24. Meenagh A, Williams F, Ross OA, et al. Frequency of cytokine polymorphisms in populations from western Europe, Africa, Asia, the Middle East and South America. Hum Immunol 2002;63: 1055-1061.

25. Padyukov L, Hahn-Zoric M, Lau YL, Hanson LA. Different allelic frequencies of several cytokine genes in Hong Kong Chinese and Swedish Caucasians. Genes Immun 2001;2:280-283.

26. Zhang L, Nie YY, Jiang YY, Li YY, Lin Y. Cannabinoid receptor 1 gene polymorphism and irritable bowel syndrome. J Gannan Med Univ 2010;30:363-367.

27. Zhang ZQ, Wang Q, Wang BJ. Relationship between TRPV1 gene polymorphism and irritable bowel syndrome. World J Gastroenterol 2009;17:3514-3518.

28. Park JM, Choi MG, Cho YK, et al. Cannabinoid receptor 1 gene polymorphism and irritable bowel syndrome in the Korean population: a hypothesis-generating study. J Clin Gastroenterol 2011; 45:45-49.

29. Spiller R, Aziz Q, Creed F, et al. Guidelines on the irritable bowel syndrome: mechanisms and practical management. Gut 2007;56: 1770-1798.

30. Lu CL, Chen CY, Chang FY, Lee SD. Characteristics of small bowel motility in patients with irritable bowel syndrome and normal humans: an Oriental study. Clin Sci (Lond) 1998;95:165-169.

31. Duan JH, Zhao HC. A clinical study on colonic motility and anorectal manometry in constipation predominant irritable bowel syndrome. Chin J Gastroenterol Hepatol 2006;15:191-193.

32. Zhan LX, Zou DW, Xu GM, Li ZS, Yin N, Zhang MQ. A study on colonic transit test and ano-manometry in functional constipation and constipation-predominant irritable bowel syndrome. Chin J Dig 2002;22:19-21.

33. Wang SH, Dong L, Luo JY, et al. A research of migrating motor complex in patients with irritable bowel syndrome. Zhonghua Nei Ke Za Zhi 2009;48:106-110.

34. Zhao JH, Dong L, Hao XQ. Small intestine motility and gastrointestinal hormone levels in irritable bowel syndrome. J South Med Univ 2007;27:1492-1495.

35. Liang RX, Zhang ZX, Cai LY, Zheng QF, Zhang FC. The study of sigmoid colon motility in patients with irritable bowel syndrome. Guangxi Medical Journal 2004;26:30-32.

36. Chen YM, Ke MY, Zhang SQ, Jiang YX. Sigmoid colon motility and gastrocolic reflex in IBS patients under ultrasonography. Chin J Dig 1999;19:272-273.

37. Chey WY, Jin HO, Lee MH, Sun SW, Lee KY. Colonic motility abnormality in patients with irritable bowel syndrome exhibiting abdominal pain and diarrhea. Am J Gastroenterol 2001;96:14991506.

38. Whitehead WE, Engel BT, Schuster MM. Irritable bowel syndrome: physiological and psychological differences between diar- 
rhea-predominant and constipation-predominant patients. Dig Dis Sci 1980;25:404-413.

39. Zhang K, Sun SB, Xie XP, Huang XQ, Hou XH. Study on accommodation and empting of proximal stomach in patients with irritable bowel syndrome. Chin J Gastroenterol Hepatol 2007;12: 298-300.

40. Stanghellini V, Tosetti C, Barbara G, et al. Dyspeptic symptoms and gastric emptying in the irritable bowel syndrome. Am J Gastroenterol 2002;97:2738-2743.

41. Van Wijk HJ, Smout AJ, Akkermans LM, Roelofs JM, ten Thije OJ. Gastric emptying and dyspeptic symptoms in the irritable bowel syndrome. Scand J Gastroenterol 1992;27:99-102.

42. Caballero-Plasencia AM, Valenzuela-Barranco M, HerreríasGutiérrez JM, Esteban-Carretero JM. Altered gastric emptying in patients with irritable bowel syndrome. Eur J Nucl Med 1999;26: 404-409.

43. Dong WZ, Zou DW, Li ZS, et al. Mechanism of hypersensitivity in the patients with irritable bowel syndrome. Chin J Dig 2004;24: $18-22$.

44. Li YQ, Wang YM, Lv GP, Gu XM, Zuo XL, Zhang HY. Effects of rectal thermal- and pressure-stimuli on visceral perception thresholds in patients with irritable bowel syndrom. Chin J Dig 2003;23:659-661.

45. Xiao WB, Liu YL, Zhao LL. The differences of rectal perception among dirrhea-dominant, constipation-dominant irritable bowel syndrome and functional constipation. World Chin J Digestol 2002;10:1291-1294.

46. Shen J, Zhu Q, Yuan RZ, Zhang ZW, Chen KM. Alterations in focal encephalic function in patients of irritable bowel syndrome. Chin J Gastroenterol Hepatol 2005;14:167-170.

47. Li QX, Yin HK, Chen LJ. Effect of tegaserod on rectal sensation thresholds in visceral hypersensitivity patients with constipation predominant irritable bowel syndrome. Chin J Postgrad Med 2007;30: 9-14.

48. Yang CM, Liu JY, Wang YQ, Zhang AZ, Ye YH. Dynamic study of anorectum in patients with irritable bowel syndrome. J Shandong Univ (Healthy Science) 2002;40:141-142.

49. Chen Q, Chen MH, Lin JK, Hu PJ. Investigation on sensation and motility in IBS patients. Chin J Dig 2003;23:241-242.

50. Mertz H, Naliboff B, Munakata J, Niazi N, Mayer EA. Altered rectal perception is a biological marker of patients with irritable bowel syndrome. Gastroenterology 1995;109:40-52.

51. Stacher G, Christensen J. Visceral hypersensitivity in irritable bowel syndrome: a summary review. Dig Dis Sci 2006; 51:440-445.

52. Zuo XL, Li YQ, Shi L, et al. Visceral hypersensitivity following cold water intake in subjects with irritable bowel syndrome. J Gastroenterol 2006;41:311-317.

53. Hasler WL. Traditional thoughts on the pathophysiology of irritable bowel syndrome. Gastroenterol Clin North Am 2011;40:21-43.

54. Yuan YZ, Tao RJ, Xu B, et al. Functional brain imaging in irritable bowel syndrome with rectal balloon-distention by using fMRI. World J Gastroenterol 2003;9:1356-1360.

55. Zuo XL, Li YQ, Huang KM, et al. Alterations in cerebral potentials evoked by rectal distention and drinking ice water in patients with irritable bowel syndrome. J Gastroenterol Hepatol 2006;21: 1844-1849.
56. Tillisch K, Mayer EA, Labus JS. Quantitative meta-analysis identifies brain regions activated during rectal distension in irritable bowel syndrome. Gastroenterology 2010;140:91-100.

57. Wang LH, Fang XC, Pan GZ. Relationship between mast cells and nerve fibers in the intestinal mucosa in patients with irritable bowel syndrome. Chin J Dig 2003;23:332-335.

58. Wang SH, Dong L, Luo JY, et al. Decreased expression of serotonin in the jejunum and increased numbers of mast cells in the terminal ileum in patients with irritable bowel syndrome. World J Gastroenterol 2007;13:6041-6047.

59. Yang YS, Feng FC, Pan DS, Zhou DY, Zhang WD, Zhang ZS. Mast cells in ilececal junction and gastrointestinal hormones in colonic mucosa in irritable bowel syndrome patients. Chin J Dig Endosc 1997;14:149-152.

60. Chen XM, Luo Y, Wu YL, Jiang M. Alterations of capsaicin receptor, substance $\mathrm{P}$ and mast cells in colonic mucosa of patients with irritable bowel syndrome. Chin J Gastroenterol Hepatol 2010;15: 672-675.

61. Chen WK, Zou YY, Li FJ, Luo D. Changes of psychosocial factors, enteral mucosal mast cells and 5-hydroxytryptamine in irritable bowel syndrome. World Chin J Digestol 2007;15:46-50.

62. Wang J, Liang LX, Zhang ZX, Li GH, Qian W, Hou XH. Alterations of enteric mucosal mast cells in patients with irritable bowel syndrome. World Chin J Digestol 2002;22:19-21.

63. Wang WA, Qian JM, Pan GZ. The role of activation of colonic mucosal mast cells in the pathophysiology of irritable bowel syndrome. Chin J Dig 2003;23:263-266.

64. Li YH, Zhu XL, Xu ZM. Changes of colonic 5-hydroxytryptamine and 5-hydroxytryptamine3 receptor in diarrhea-predominant irritable symptom. Chin J Gastroenterol Hepatol 2006;11:477-480.

65. Li ZS, Zhan LX, Zhou DW, Xu GM, Man XH, Ye XT. Morphological and functional alteration of serotonin-producing intestinal enterochromaffin cells in patients with irritable bowel syndrome. Chin J Dig 2004;24:94-97.

66. Zhan LX, Xu GM, Li ZS, Zou DW, Jin ZD, Tu ZX. Plasma 5-HT, 5-HIAA elevated in patients with irritable bowel syndrome at active stage and remission stage. Acad J Mil Med Univ 2003; 24:152-154.

67. Zuo XL, Li YQ, Guo M, et al. Relationship between the symptomatology and plasma 5-hydroxytryptamine concentrations after cold water intake in patients with diarrhea predominant irritable bowel syndrome. Chin J Dig 2007;27:516-519.

68. Pan GZ, Lu SC, Ke MY, Han SM, Guo HP, Fang XC. An epidemiologic study of irritable bowel syndrome in Beijing-A stratified randomized study by clustering sampling. Chin J Epidemiol 2000; 21:26-29.

69. Xiong LS, Chen MH, Chen HX, Xu AG, Wang WA, Hu PJ. A population-based epidemiologic study of irritable bowel syndrome in South China: stratified randomized study by cluster sampling. Aliment Pharmacol Ther 2004;19:1217-1224.

70. Wang LH, Fang XC, Pan GZ. Bacillary dysentery as a causative factor of irritable bowel syndrome and its pathogenesis. Gut 2004; 53:1096-1101.

71. Thabane M, Kottachchi DT, Marshall JK. Systematic review and meta-analysis: The incidence and prognosis of post-infectious irritable bowel syndrome. Aliment Pharmacol Ther 2007;26:535-544. 
72. Ji S, Park H, Lee D, Song YK, Choi JP, Lee SI. Post-infectious irritable bowel syndrome in patients with Shigella infection. J Gastroenterol Hepatol 2005;20:381-386.

73. Yakoob J, Jafri W, Jafri N, et al. Irritable bowel syndrome: in search of an etiology: role of Blastocystis hominis. Am J Trop Med Hyg 2004;70:383-385

74. Ghoshal UC, Park H, Gwee KA. Bugs and irritable bowel syndrome: The good, the bad and the ugly. J Gastroenterol Hepatol 2010;25:244-251.

75. Linghu EQ, Yang YS. Analysis of peripheral blood lymphocytes subgroup in irritable bowel syndrome. Chin J Dig 2002;22:423425.

76. Yang TX, Zhang ZK, Zeng HL, et al. T-lymphocytes subgroups of peripheral blood and enteromucosal mast cells in patients with irritable bowel syndrome. Qingdao Med J 2008;40:85-87.

77. Song JZ, Wang QM, Ding XP, Yu Y. Change of mucous neuropeptide and IL-1 $\beta$ in IBS. Chin J Gastroenterol Hepatol 2007; 16:219-222.

78. Ju H, Zhang XF, Liu XS, Wei LZ. Correlations of substance P with interleukin-2 and interferon- $\gamma$ expression in colonic mucosa of patients with post- and non-post-infectious irritable bowel syndrome. World Chin J Digestol 2006;14:3116-3120.

79. Liang HQ, Wang SH, Li YQ, Wang FS. Analysis on expression imbalance of peripheral blood inflammatory cytokines in patients with irritable bowel symptom. Chin J Gastroenterol 2008;13:111113.

80. Zhang R, Zhang XH, Sun MY, Zhang HT, Yang AJ, Wang FX. Alternation of IL-8 and TNF in irritable bowel syndrome. Chin J Celiopath 2004;4:7-10.

81. Li YQ, Zhang HY, Zuo XL, Yuan HP, Lu XF, Li JM. Study on the shifting of Th1/Th2 balance of large intestinal mucosa in patients with irritable bowel syndrome. Chin J Dig 2004;24:728-731.

82. Wu P, Zhang HY, Zhang B, Lu B, Wu MB, Lv YL. Change of cytokine in irritable bowel syndrome and the clinical significance. J Chin Physci 2006;8:1406-1407.

83. Hua MC, Lai MW, Kuo ML, Yao TC, Huang JL, Chen SM. Decreased interleukin-10 secretion by peripheral blood mononuclear cells in children with irritable bowel syndrome. J Pediatr Gastroenterol Nutr 2011;52:376-381.

84. Fu Y, Tong JJ, Pan Q, et al. Phenotypic analysis of Th cells in colon and peripheral blood in patients with irritable bowel syndrome. Zhonghua Yi Xue Za Zhi 2009;89:2120-2123.

85. Spiller R, Garsed K. Postinfectious irritable bowel syndrome. Gastroenterology 2009;136:1979-1988.

86. Ortiz-Lucas M, Saz-Peiró P, Sebastián-Domingo JJ. Irritable bowel syndrome immune hypothesis. Part two: the role of cytokines. Rev Esp Enferm Dig 2010;102:711-717.

87. Ortiz-Lucas M, Saz-Peiró P, Sebastián-Domingo JJ. Irritable bowel syndrome immune hypothesis. Part one: the role of lymphocytes and mast cells. Rev Esp Enferm Dig 2010;102:637-647.

88. Eswaran S, Tack J, Chey WD. Food: the forgotten factor in the irritable bowel syndrome. Gastroenterol Clin North Am 2011;40:141162.

89. Zhang XD, Deng M, Li M, Wan XL. Food intolerance and diarrhea-dominant irritable bowel syndrome. World Chin J Digestol 2007; 15:3877-3879.
90. Zuo XL, Li YQ, Li WJ, et al. Alterations of food antigen-specific serum immunoglobulins $\mathrm{G}$ and $\mathrm{E}$ antibodies in patients with irritable bowel syndrome and functional dyspepsia. Clin Exp Allergy 2007;37:823-830.

91. Xu WB, Zhu JQ. The effect of the specific food $\operatorname{IgG}$ and $\operatorname{IgE}$ on the pathogenesis of irritable bowel syndrome. Acad Jiangxi 2008; 48:68-70.

92. Yang CM, Li YQ. The examination of the food-specific antibodies $\operatorname{IgG}$ and $\operatorname{IgE}$ in patients with irritable bowel syndrome. Chin J Dig Endosc 2007;24:346-349.

93. Park MI, Camilleri M. Is there a role of food allergy in irritable bowel syndrome and functional dyspepsia? A systematic review. Neurogastroenterol Motil 2006;18:595-607.

94. Atkinson W, Sheldon TA, Shaath N, Whorwell PJ. Food elimination based on IgG antibodies in irritable bowel syndrome: a randomised controlled trial. Gut 2004;53:1459-1464.

95. Niec AM, Frankum B, Talley NJ. Are adverse food reactions linked to irritable bowel syndrome? Am J Gastroenterol 1998;93: 2184-2190.

96. Zar S, Kumar D, Benson MJ. Food hypersensitivity and irritable bowel syndrome. Aliment Pharmacol Ther 2001;15:439-449.

97. Fu CW, Xu B, Chen WQ, Luan RS, Zhan SY. Cross-sectional study on the prevalence of depressive, anxiety disorder in outpatients with irritable bowel syndrome and functional dyspepsia in urban China. Chin J Dig 2006;26:151-154.

98. Dong YY, Zuo XL, Li CQ, Yu YB, Zhao QJ, Li YQ. Prevalence of irritable bowel syndrome in Chinese college and university students assessed using Rome III criteria. World J Gastroenterol 2010;16:4221-4226.

99. Shen L, Kong H, Hou X. Prevalence of irritable bowel syndrome and its relationship with psychological stress status in Chinese university students. J Gastroenterol Hepatol 2009;24:1885-1890.

100. Lee S, Wu J, Ma YL, Tsang A, Guo WJ, Sung J. Irritable bowel syndrome is strongly associated with generalized anxiety disorder: a community study. Aliment Pharmacol Ther 2009;30:643-651.

101. Wang WA, Pan GZ, Qian JM. Effect of psychological factors on visceral sensation of patients with irritable bowel syndrome. Zhonghua Yi Xue Za Zhi 2002;82:308-311.

102. He JQ, Wang WA, Hu PJ. Coping characters of patients with irritable bowel syndrome. Chin J Dig 2003;23:527-529.

103. Wang W, Pan G, Qian J. Cognitive therapy for patients with refractory irritable bowel syndrome. Zhonghua Nei Ke Za Zhi 2002; 41:156-159.

104. Song DL, Wang MX, Zeng J, Li YQ. Effect of psychological treatment for patients with irritable bowel syndrome. J Shandong Univ (Healthy Science) 2007;45:1068-1071.

105. Hou XH, Zhang JK, Yi CQ, et al. The changes of fecal microflora in irritable bowel syndrome with diarrhea. Chin J Dig 1990;2:7274.

106. Si JM, Yu YC, Fan YJ, Chen SJ. Intestinal microecology and quality of life in irritable bowel syndrome patients. World J Gastroenterol 2004;10:1802-1805.

107. Chen ST, Huang HY, Zhang SZ, Chen RL. Observation and analysis of intestinal microecology in patients with diarrhea-predominant irritable bowel syndrome. China Modern Doctor 2009;47:9497. 
108. Zhang L. Significance of intestinal tract normal bacteria flora quantitative analysis of IBS sufferers. China Medical Herald 2008;5:9495.

109. Lin JK, Hu PJ, Li YY, Nie YQ, Zhao YH, Lin MP. A multi-center double-blind randomized controlled trial in the treatment of irritable bowel syndrome with bifidobacteria. Chin J Dig 2003;23:755756.

110. Zhu LM, Ke MY, Zhou LY, et al. A clinical trail of probiotics in the treatment of IBS-D. Basic and Clinical Medicine 2008;28: 1070-1074.

111. Fan YJ, Chen SJ, Yu YC, Si JM, Liu B. A probiotic treatment containing Lactobacillus, Bifidobacterium and Enterococcus improves
IBS symptoms in an open label trial. J Zhejiang Univ Sci B 2006; 7:987-991.

112. Zeng J, Li YQ, Zuo XL, Zhen YB, Yang J, Liu CH. Clinical trial: effect of active lactic acid bacteria on mucosal barrier function in patients with diarrhoea-predominant irritable bowel syndrome. Aliment Pharmacol Ther 2008;28:994-1002.

113. Salonen A, de Vos WM, Palva A. Gastrointestinal microbiota in irritable bowel syndrome: present state and perspectives. Microbiology 2010;156(Pt 11):3205-3215.

114. Parkes GC, Sanderson JD, Whelan K. Treating irritable bowel syndrome with probiotics: the evidence. Proc Nutr Soc 2010;69:187194. 